\title{
Kearifan Lokal Kabumi: Media Internalisasi Nilai- Nilai Karakter Masyarakat Tuban Jawa Timur
}

\author{
Ahmad Arif Widianto ${ }^{\mathrm{a}, 1}$, Rose Fitria Lutfiana ${ }^{\mathrm{b}, 2^{*}}$ \\ aniversitas Negeri Malang, Jalan Semarang 5, Malang, 65145, Indonesia \\ b Universitas Muhammadiyah Malang, Jalan Raya Tologomas 246 Malang, 65144, Indonesia \\ ${ }_{1}^{1}$ ahmad.arif.fis@um.ac.id ${ }^{2}$ rose@umm.ac.id
}

* Corresponding Author

\begin{tabular}{ll}
\hline INFO ARTIKEL & ABSTRAK \\
\hline Sejarah Artikel: & Kearifan lokal berperan penting dalam kehidupan masyarakat, \\
Diterima: 8 Maret 2021 & utamanya di tengah gencarnya arus modernisasi. Hal ini berdampak \\
Direvisi: 27 Maret 2021 & terhadap perubahan sosial di masyarakat. Kabumi sebagai salah satu \\
Disetujui: 8 April 2021 & kearifan lokal menjadi media penting bagi internalisasi nilai-nilai \\
Tersedia Daring: 10 April 2021 & karakter masyarakat. Penelitian ini bertujuan untuk mendeskripsikan \\
\hline Kata Kunci: & kearifan lokal kabumi sebagai media internalisasi pendidikan karakter \\
Internalisasi & bagi masyarakat di Desa Bader, Kecamatan Jatirogo, Kabupaten Tuban. \\
Kabumi & Metode penelitian yang digunakan adalah kualitatif deskriptif. \\
Karakter & Penelitian dilakukan di Desa Bader, Kecamatan Jatirogo, Kabupaten \\
Kearifan lokal & Tuban. Subjek penelitian ini adalah kepala desa, sesepuh desa, dan \\
& masyarakat Desa Bader. Pengumpulan data dilakukan dengan \\
& wawancara, observasi, dan studi dokumentasi. Teknik analisis data \\
& menggunakan model Miles dan Hubberman. Uji keabsahan data \\
& menggunakan triangulasi sumber. Hasil penelitian menunjukkan bahwa \\
& proses internalisasi nilai-nilai karakter dilakukan melalui lima tahapan, \\
& yaitu penerimaan nilai, respon, seleksi nilai, internalisasi, dan \\
& aktualisasi. Di sisi lain, nilai-nilai karakter yang muncul sebagai bentuk \\
& internalisasi kearifan lokal kabumi antara lain nilai religius, gotong \\
& royong, toleransi, dan peduli lingkungan.
\end{tabular}

\begin{tabular}{ll}
\hline ABSTRACT \\
\hline $\begin{array}{l}\text { Keywords: } \\
\text { Internalization }\end{array}$ Labumi \\
Character \\
Local wisdom
\end{tabular}$\quad \begin{aligned} & \text { midst of modernization. This phenomenon has an impact on social } \\
& \text { change in society. Kabumi as one of the local wisdoms is an important } \\
& \text { medium for internalizing character values in society. This study aims to } \\
& \text { describe the local wisdom of Kabumi as a medium for internalizing } \\
& \text { character education for the community in Bader Village, Jatirogo District, } \\
& \text { Tuban Regency. The research method used is descriptive qualitative. } \\
& \text { This research was conducted in Bader village, Jatirogo district, Tuban } \\
& \text { district. The subjects in this study were the village head, village elders } \\
& \text { and the Bader village community. Data collection was carried out by } \\
& \text { interview, observation, and documentation. The data analysis technique } \\
& \text { used the Miles and Hubberman technique. The data validity test used } \\
& \text { source triangulation. The results showed that the process of } \\
& \text { internalizing character values was carried out in five stages, namely } \\
& \text { acceptance of value, providing response, value selection, internalization } \\
& \text { and actualization. On the other hand, the character values that appear as } \\
& \text { a form of internalization through local Kabumi wisdom include religious } \\
& \text { values, mutual cooperation, tolerance, and environmental care. }\end{aligned}$


How to Cite: Widianto, A. A., \& Lutfiana, R. F. (2021). Kearifan Lokal Kabumi: Media Internalisasi Nilai-Nilai Karakter Masyarakat Tuban Jawa Timur. Satwika : Kajian Ilmu Budaya dan Perubahan Sosial, 5 (1), 118-130. doi: 10.22219/satwika.v5i1.15929

\section{Pendahuluan}

Indonesia adalah negara yang terdiri dari banyak kepulauan dari Sabang hingga Merauke dengan kebudayaan yang beragam. Keragaman membentuk perbedaan karakteristik sumberdaya alam dan budaya, tidak hanya di wilayah perairan tetapi juga agraris. Kebudayaan pada masing-masing wilayah dipengaruhi oleh lokalitas khas yang diwariskan secara turun-temurun. Oleh karena itu, Indonesia termasuk salah satu negara multikultural terbesar di dunia (Lestari, 2015). Keragaman karakteristik masyarakat mereproduksi kearifan lokal yang beragam sesuai konteks sosial, budaya, dan geografis.

Masyarakat agraris juga memiliki kearifan lokal tersendiri, baik material atau non-material. Kearifan lokal tersebut terbentuk melalui proses adaptasi dan kreativitas masyarakat dalam berinteraksi dengan lingkungan. Pengolahan lahan pertanian tidak hanya berkaitan dengan sistem perekonomian saja melainkan juga memuat aspek-aspek budaya yang menjadi kearifan lokal masyarakat. Aspek budaya (tradisi) tersebut menyangkut ritual, kepercayaan, pengetahuan, dan keterampilan. Nilai-nilai budaya tidak hanya menjadi pelengkap dalam proses produksi di pertanian, tetapi juga menjadi landasan berpikir dan bertindak dalam pengolahan lahan (Hadi, 2013:58).

Tradisi-tradisi dalam pertanian di beberapa wilayah Indonesia dipandang sebagai rutinitas tahunan yang wajib dilakukan. Hal tersebut karena terdapat kepercayaan bahwa tradisi merupakan bagian dari upaya menjaga keberlangsungan pertanian. Tradisi yang dilakukan baik pra maupun pascapanen juga dipandang sebagai media interaksi dan pengharapan pada Tuhan maupun kekuatan-kekuatan yang dapat memberikan kesuburan.
Kearifan lokal atau local wisdom menjadi sebuah kekuatan yang mampu membentuk kondisi masyarakat yang harmonis antarmanusia serta manusia dengan komunitasnya. Di beberapa daerah, tradisi masyarakat pertanian mampu mempererat integrasi sosial. Misalnya, upacara aruh baharain di masyarakat Dayak setelah musim panen padi huma, seren taun di masyarakat Sunda untuk menyambut panen raya, wiwitan dalam masyarakat Jawa sebelum panen padi sebagai bentuk terimakasih dan syukur kepada Bumi dan Dewi Sri (Dewi Padi), ataupun mambiak di Sumatera Barat sebagai rasa syukur pada Tuhan yang kuasa (Tabloid Desa, 2016).

Dalam konteks tersebut, kearifan lokal mampu berkontribusi dalam tertatanya kehidupan masyarakat yang adil, rukun, selaras, saling menghormati dan menghargai antarumat beragama. Kearifan lokal bisa menjadi kekuatan yang mampu membuat sebuah masyarakat kondusif melalui interaksi yang terjadi sesama manusia serta dengan komunitasnya (Sudarma, 2007). Dengan memahami hakikat kearifan lokal masyarakat dapat menciptakan kehidupan yang harmoni sesuai dengan Pancasila.

Tradisi kabumi dalam masyarakat Bader Jatirogo termasuk kearifan lokal dalam pertanian. Kata kabumi berasal dari istilah sedekah bumi yang kemudian disingkat untuk mempermudah penyebutan. Sebenarnya, tradisi ini juga terdapat di daerah-daerah lain di sekitar Jawa Tengah, seperti Kudus, Rembang, dan Pati. Namun, ada keunikan dalam ritual kabumi di Bader. Dalam pelaksanaannya, masyarakat mencampurkan nilai-nilai Islam dan kepercayaan pada kekuatan gaib yang diyakini dapat memberikan panen yang melimpah. Ritual kabumi dilakukan setelah panen padi. Namun ritual baru dilakukan setelah padi milik petinggi (kepala desa) 
dipanen. Hal tersebut karena kedudukan perangkat desa dan tokoh masyarakat berperan penting dalam prosesi kabumi sehingga harus didahulukan.

Tradisi-tradisi dalam pertanian mencerminkan kearifan lokal masyarakat dalam berinteraksi dan memanfaatkan lingkungan. Kearifan lokal mencakup pengetahuan, keyakinan, dan nilai-nilai budaya masyarakat yang mengatur hubungan sesama manusia, manusia dengan alam, dan manusia dengan Tuhan (Bustami, 2013:9-10). Konteks inilah yang menyebabkan masyarakat tidak dapat bebas dalam memanfaatkan sumber daya alam yang tersedia. Tindakan masyarakat harus didasarkan pada nilai-nilai yang disosialisasikan dan dipraktikkan secara turun-temurun.

Dalam konteks sosial-budaya, kabumi dapat berperan penting dalam hubungan masyarakat, terutama internalisasi nilai-nilai karakter. Internalisasi berlangsung melalui prosesi kabumi sebagai tradisi pertanian. Dalam setiap tahapan prosesi mencerminkan proses sosial yang mendorong terwujudnya karakter positif dalam kehidupan masyarakat. Di sisi lain, kabumi menjadi sistem pengetahuan lokal dalam memahami aspek ekologis yang berpengaruh dalam perekenomian masyarakat.

Kabumi sebagai produk kebudayaan di Desa Bader merupakan salah satu bentuk pendidikan informal yang ada di masyarakat. Budaya tidak hanya dimaknai secara sempit yang hanya terbatas pada konservasi, namun lebih dari itu sebagai transformasi proses pendidikan (Al Muchtar, 2004). Pendekatan budaya sering diabaikan karena sifatnya yang cenderung evolusioner dalam menyelesaikan persoalan. Karakter terbentuk secara evolusioner. Suatu tindakan, perilaku, dan sikap seseorang yang terjadi membutuhkan proses sebelumnya yang kemudian membuat sikap dan perilaku yang melekat pada diri mereka.

Pada konteks ini, kabumi berperan penting sebagai media internalisasi nilainilai karakter pada masyarakat Jatirogo. Hal tersebut karena kabumi sebagai bagian dari tradisi masyarakat agraris memuat nilai-nilai sosial dan sistem pengetahuan lokal yang dilestarikan secara turun-temurun. Berbagai tahap prosesi kabumi merepresentasikan proses sosial masyarakat, termasuk juga internalisasi nilai -nilai karakter. Pendekatan kebudayaan dalam pembentukan karakter masyarakat dinilai efektif karena sudah melekat dan sesuai corak masyarakat. Dengan demikian, kabumi sebagai media internalisasi secara tidak langsung mendorong proses reproduksi sosial.

Berdasarkan realitas di atas, penelitian ini penting dilakukan untuk mengetahui peran kearifan lokal kabumi sebagai media internalisasi karakter pada masyarakat Jatirogo. Beberapa penelitian terdahulu sebenarnya sudah menunjukkan hasil yang serupa dengan penelitian ini. Seperti yang dilakukan oleh Maisyanah \& Inayati (2018) tentang "Internalisasi Nilai-nilai Pendidikan Agama Islam pada Tradisi Meron" yang memuat nilai menaati pemimpin, memelihara kesejahteraan bersama, dan memiliki sikap toleransi.

Hasil penelitian dari Lemianti et. al. (2020) juga menunjukkan kesimpulan serupa. Menurutnya, terdapat beberapa nilai yang terkandung dalam kearifan lokal gong waning di antaranya nilai budaya, nilai ungkapan syukur, nilai saling menghargai, dan nilai harmonis.

Begitu juga penelitian oleh Mahardika dan Darmawan (2016) yang menunjukan bahwa kebudayaan masyarakat Bali Aga di desa Trunyan terdiri dari Mepasah, Ngayah, Paruman, dan Barong Brutuk. Dalam kebudayaan tersebut terdapat nilai-nilai kearifan lokal, yaitu konsep menyama braya.

Berbeda dari penelitian di atas, penelitian ini tidak hanya melihat nilai-nilai karakter yang terkandung pada kearifan lokal kabumi saja, melainkan juga peran dan proses kabumi sebagai media internalisasi nilai-nilai karakter pada masyarakat agraris di Jatirogo Tuban. Beberapa poin yang akan dibahas dalam artikel ini adalah posisi penting kabumi pada masyarakat Jatirogo dan dinamikanya, serta peran kabumi 
sebagai media internalisasi nilai dan nilainilai karakter yang terkandung dalam prosesinya. Penelitian ini diharapkan dapat bermanfaat dalam pengembangan wacana keilmuan tentang kearifan lokal serta menjadi rekomendasi bagi pemerintah maupun tokoh masyarakat untuk merevitalisasi kearifan lokal sebagai media internalisasi nilai-nilai sosial-budaya di masyarakat.

\section{Metode}

Penelitian ini menggunakan jenis dan pendekatan kualitatif deskriptif. Penelitian dilakukan di Desa Bader, Kecamatan Jatirogo. Desa Bader dipilih menjadi lokasi penelitian karena desa ini memiliki karakteristik dan keunikan dibandingkan desa lain yang memiliki adat atau tradisi kabumi. Keunikannya adalah masyarakat Desa Bader masih mempraktikkan tradisi kabumi yang sarat dengan kepercayaan pada hal mistis (danyang) meskipun terletak tidak jauh dari pusat pemerintahan (kecamatan) yang sarat modernitas. Di sisi lain, ada perubahan prosesi kabumi yang penting dibahas untuk mengetahui pengaruhnya pada proses internalisasi nilai-nilai karakter.

Penelitian ini dilakukan pada April-Juni pada 2020. Subjek penelitian ini adalah masyarakat Jatirogo. Sumber data penelitian ini adalah informan, dokumentasi, dan hasil observasi. Informan terdiri dari aparatur desa, tokoh masyarakat, dan masyarakat Desa Bader. Penentuan informan dilakukan dengan teknik purposive sampling, yaitu peneliti memilih informan yang sesuai dengan tujuan penelitian. Informan dipilih berdasarkan kriteria pemahaman dan keterlibatannya dengan sejarah, dinamika, dan prosesi kabumi. Teknik pengumpulan data yang digunakan adalah wawancara, observasi, dan studi dokumentasi. Studi dokumentasi dilakukan untuk mengumpulkan data dari literatur, laporan, dokumen, dan kebijakan atau peraturan desa yang berkaitan dengan kabumi. Adapun hasil observasi berupa pengamatan bentuk dan prosesi kabumi, karakteristik sosialbudaya masyarakat. Data yang digali adalah terkait dengan kebijakan pemerintah desa, karakteristik masyarakat, pelaksanaan kabumi, pandangan informan terhadap kabumi, serta internalisasi nilai karakter melalui kabumi.

Dalam penelitian ini peneliti bertindak sebagai key instrumen atau instrumen kunci selain itu juga digunakan pedoman wawancara, pedoman observasi, dan pedoman studi dokumentasi. Teknik analisis data menggunakan teknik Milles \& Huberman yang terdiri dari empat tahap, yaitu pengumpulan data, reduksi data, penyajian data, dan kesimpulan. Uji validitas yang digunakan yaitu triangulasi sumber data dan member check.

\section{Hasil dan Pembahasan}

\subsection{Kabumi: Kearifan Lokal dan Reproduksi Sosial-Budaya Masyarakat Pertanian Jatirogo}

Secara umum masyarakat mempunyai sebuah sistem pengetahuan dan pengelolaan lokal yang diturunkan secara turun-temurun untuk dikembangkan dan dilestarikan. Masyarakat memiliki ikatan sosial, budaya, dan religius yang erat dengan lingkungan lokalnya.

Kearifan lokal menjadi cermin sistem pengetahuan dan kebiasaan hidup masyarakat yang telah berlangsung lama. Keberlangsungan tersebut terlihat dari norma dan nilai yang berlaku pada masyarakat tertentu. Norma dan nilai tersebut menjadi pegangan kelompok masyarakat tertentu yang biasanya akan menjadi pegangan hidup yang bisa kita lihat dari sikap ataupun perilaku mereka.

Ditinjau dari makna etimologisnya, kearifan lokal terdiri dari dua suku kata yaitu kearifan dan lokal. Definisi kata kearifan yaitu kemampuan seseorang dalam menggunakan pikirannya untuk menyikapi suatu kejadian, objek, atau situasi. Kata lokal mempunyai makna ruang interaksi, yaitu peristiwa atau situasi terjadinya suatu hal. Dapat ditarik kesimpulan bahwa kearifan lokal secara substansial merupakan sebuah norma yang berlaku dan hidup di masyarakat sebagai bentuk dasar dan pandangan hidup 
dalam bersikap serta berperilaku dalam kehidupan sehari-hari. Oleh karenanya kearifan lokal dipandang sebagai sebuah identitas yang menentukan suatu harkat dan martabat seseorang dalam komunitasnya.

Secara substansial, kearifan lokal merupakan sebuah norma dan nilai yang berlaku di masyarakat. Norma dan nilai tersebut oleh masyarakat diyakini kebenarannya sehingga dijadikan sebagai pedoman dalam bertingkah laku sehari-hari. Hal tersebut tampak begitu rasional jika disimpulkan bahwa kearifan lokal adalah sebuah entitas yang sangat menentukan harkat dan martabat serta unsur kecerdasan, kreativitas, dan pengetahuan lokal dari para elite dan masyarakat yang menentukan dalam pembangunan peradaban masyarakat.

Kearifan lokal dalam sudut pandang Gobyah (2003) dipandang sebagai suatu kebenaran yang sudah menjadi tradisi di masyarakat. Ridwan (2007) mengartikan kearifan lokal atau local wisdom sebagai usaha manusia dengan menggunakan akal budinya untuk bertindak dan bersikap terhadap suatu objek atau peristiwa yang terjadi dalam ruang tertentu. Ketika kita melakukan analisa kearifan lokal yang dipandang sebagai bentuk kebudayaan, maka hal tersebut akan mengalami reinforcment secara terus menerus ke arah yang lebih baik. Sebagai sebuah bentuk manifestasi yang terjadi akibat penguatanpenguatan dalam kehidupan sehari-hari, kearifan lokal merupakan wujud humanisasi manusia dalam berbudaya.

Sebagai bagian dari kekayaan lokal yang mempunyai kaitan erat dengan pandangan hidup atau way life, kearifan lokal atau local wisdom mempunyai peranan untuk mengakomodasikan berbagai kebijakan yang disesuaikan dengan tradisi yang dimiliki oleh suatu daerah. Hal ini berdampak tidak hanya pada norma dan nilai-nilai budaya masyarakat, tetapi juga segala unsur gagasan atau ide, yang berimplikasi pada teknologi sebagai akibat dari globalisasi, penanganan kesehatan, pembangunan dan estetika yang hidup di masyarakat.
Desa Bader memiki kearifan lokal (local wisdom) yang masih hidup dalam masyarakat hingga saat ini. Salah satu kearifan lokal tersebut, yaitu kabumi. Eksistensi kabumi sebagai kearifan lokal sampai saat ini masih dipertahankan dan dilestarkan oleh masyarakat Desa Bader. "Kabumi" merupakan istilah yang sering disebut oleh masyarakat Desa Bader. Kata ini merupakan sebutan untuk sedekah bumi.

Desa Bader adalah sebuah desa yang terletak di Kecamatan Jatirogo, Tuban. Lokasi Desa Bader tidak jauh dari pusat pemerintahan, bahkan menjadi salah satu jalan utama antarkecamatan di Tuban. Sebelah Utara, Desa Bader berbatasan dengan Desa Besowo. Sebelah Selatan berbatasan dengan Desa Paseyan. Sebelah Timur berbatasan dengan Desa Sadang dan di Barat berbatasan dengan Desa Wangi. Jumlah penduduk di desa ini sebanyak 2181 jiwa, terdiri dari 594 Kepala Keluarga (KK). Masyarakat Bader sebagian besar bermata pencaharian sebagai petani. Meskipun sebenarnya sumber daya alam berupa hutan juga tersedia. Lahan yang menjadi sumber mata pencaharian masyarakat Bader seluas 310 ha, terdiri dari lahan sawah tadah hujan seluas 55 ha dan lahan tegal seluas 240 ha.

Besarnya kecenderungan masyarakat pada pertanian terlihat dari adanya penambahan sawah baru seluas 17 ha, sedangkan perubahan sawah menjadi non sawah hanya 2 ha. Namun, mayoritas masyarakat yang menjadi petani didominasi laki-laki sebanyak 257 orang, sedangkan perempuan hanya 45 orang. Hal tersebut karena laki-laki sebagai tulang punggung keluarga sehingga berkewajiban menafkahi keluarga dengan mengandalkan sektor pertanian, baik sebagai buruh tani maupun pemilik lahan. Perempuan lebih banyak beraktivitas di wilayah domestik atau rumah tangga.

Visi desa Bader yaitu terwujudnya desa Bader yang religius, maju, bermartabat dan berkualitas. Misinya antara lain: (1) meningkatkan nilai-nilai keagamaan melalui kegiatan spiritual yang berkelanjutan dengan berpedoman norma- 
norma agama, (2) meningkatkan kualitas pelayanan umum melalui pembangunan infrastruktur dasar dan pelayanan public, (3) meningkatkan kualitas hidup masyarakat melalui pendidikan, kesehatan, dan pelestarian lingkungan hidup, (4) meningkatkan pembangunan ekonomi masyarakat melalui agro komplek, baik sarana dan prasarana serta Usaha Mikro Kecil dan Menengah (UMKM), dan (5) meningkatkan harmonisasi kehidupan beragama dan berbudaya, supremasi hukum, dan tata kelola pemerintahan yang baik.

Masyarakat Desa Bader, sebagai masyarakat agraris, masih melangsungkan ritual pertanian kabumi untuk mengungkapkan rasa syukur pada Tuhan atas hasil panen padi yang didapat. Ritual kabumi adalah hasil reproduksi kultural masyarakat yang mencampurkan aspek kepercayaan pada Tuhan dan kekuatan gaib sekaligus.

Ritual Kabumi yang ada di Desa Bader memiliki keunikan jika dibandingkan tradisi serupa yang ada di daerah lain. Hal ini disebabkan dalam pelaksanaannya masyarakat Desa Bader masih memiliki kepercayaan pada "danyang" sebagai punjer kekuatan gaib yang ada di Desa Bader dan juga nilai-nilai Islam yang sebagian besar dianut oleh masyarakat. "Danyang" merupakan hal gaib yang dianggap oleh masyarakat memiliki kekuatan untuk membuat hasil panen masyarakat melimpah ruah dan menjaga masyarakat dari bala atau bencana.

Berdasarkan hasil wawancara dengan Basuki (5/2020) selaku tokoh masyarakat, adanya kabumi dilakukan untuk menjalin relasi transendental dengan makhluk gaib dan Tuhan yang Maha Esa. Berikut petikan wawancaranya:

"Sesaji yang diberikan sesuai dengan apa yang diingini makhluk gaib. Sesaji diberikan ke sumur untuk mengungkapkan rasa syukur karena air yang diambil. Yang ikut menari bersama tandak bergantian, dari perangkat desa tertinggi ke yang rendah".
Petikan wawancara di atas semakin menegaskan argumen bahwa kepercayaan mistis masih berpengaruh pada masyarakat agraris. Bagi masyarakat pertanian, prosesi ini sudah berlangsung sejak lama dan dipercaya mempengaruhi hasil panen. Hal tersebut karena ada rasa ketidakpercayaan dan ketidakberdayaan terhadap kapasitas diri untuk menjamin keberhasilan panen berikutnya sehingga meminta bantuan pada kekuatan gaib atau Tuhan (Hardika, 2009:146). Meskipun sebenarnya di beberapa daerah ritual-ritual mistis mulai memudar karena rasionalitas dan modernisasi masyarakat telah berkembang (Hardika, 2009:150), namun ada sebagian masyarakat yang masih mempertahankannya. Artinya, meskipun laju modernisasi berikut pemikiran masyarakat telah berkembang namun pada praktiknya masih ada kepercayaan pada kekuatan gaib. Pemikiran masyarakat, meminjam istilah Comte (Ritzer, 2010), yang sudah sampai tahap positif masih mengakui praktik-praktik irasionalitas meskipun ada pergeseran.

Lebih lanjut, informan tersebut menyatakan sebagai berikut

\section{"Orang-orang memberi makanan, (Selamatan) di 3 makam (Punden). Karena kabumi itu termasuk sedekah bumi, termasuk sodaqoh, atas panen yang diambil dari air sumber atau sumur. Pelaksanaan harus di tempat tersebut, tidak di musolla karena melestarikan tradisi."}

Wawancara di atas menguatkan bahwa ritual-ritual pertanian menjadi bukti bahwa nilai-nilai kearifan lokal mempengaruhi rutinitas masyarakat dalam rangka beradaptasi dan berinteraksi dengan lingkungan alam. Bahkan, nilai-nilai budaya memberikan inspirasi dan menjadi landasan dalam mengolah lahan pertanian (Hadi, 2013:58). Aktivitas (praxis) masyarakat dalam mengolah pertanian didasarkan pada sistem kepercayaan (cosmos) dan sistem pengetahuan atau kognitif (corpus) 
(Iskandar, 2016:28). Sistem kepercayaan masyarakat pertanian sering berkaitan dengan unsur mistis karena adanya pemahaman bahwa perlu menghubungkan alam nyata dengan alam gaib untuk menyeimbangkan kehidupan (Hardika, 2009; Hartati, 2012). Kekuatan-kekuatan gaib tersebut tidak selalu bersifat supernatural yang abstrak, tetapi juga dianggap ada dalam diri manusia dan bersemayam pada benda di sekitar (Hartati, 2012).

Tradisi Kabumi dilakukan setiap satu tahun sekali setelah selesai panen raya. Panen raya di sini mengandung artian ritual kabumi baru bisa dilakukan jika masyarakat telah panen padi. Selain itu terdapat syaratsyarat khusus terkait pelaksanaan ritual kabumi, di antaranya (1) jika masyarakat desa mayoritas bahkan semuanya sudah panen padi, namun saat pagi petinggi atau kepala desa belum panen maka ritual kabumi belum bisa dilaksanakan. Hal ini dikarenakan kedudukan petinggi memiliki peran sentral dalam prosesi kabumi dan sebagai bentuk rasa hormat masyarakat, (2) pelaksanaan Kabumi harus dilaksanakan pada hari rabu pon, karena bagi masyarakat hari tersebut merupakan hari baik. Penentuan hari didasarkan pada penanggalan Jawa yang diajarkan secara turun-temurun. Namun, masyarakat juga mempercayai waktu-waktu tertentu dalam penanggalan Jawa yang tidak baik untuk menyelenggarakan kabumi yang disebut taliwangke. Waktu-waktu tersebut adalah ruah, poso, suro, dan selo. Ada juga satu waktu khusus yang tidak boleh untuk acara kabumi meskipun bertepatan hari rabu yang disebut tompo seren, yaitu 1 suro.

Prosesi kabumi dimulai dengan arakarakan makanan (kesukaan danyang) dari para warga yang dibawa ke tiga tempat keramat disebut punden secara bergiliran. Ketiga tempat terdiri dari dua sumur dan satu makam yang dipercayai sebagai peninggalan para danyang (leluhur Desa Bader). Ritual diawali dengan pembukaan oleh tokoh masyarakat lalu disusul doa dan memberikan sesajen di atas wadah yang dipimpin oleh modin (perangkat desa bidang agama). Doa ditujukan kepada Tuhan sebagai rasa syukur dan pengharapan supaya pertanian mendatang jadi lebih baik. Modin juga mendoakan arwah leluhur yang dianggap masih "mendiami" tiga punden dengan harapan mendapat berkah supaya pertanian makmur.

Eksistensi tradisi kabumi dapat bertahan sampai saat ini selain karena sudah menjadi warisan budaya juga tidak bertentangan dengan peraturan negara. Bahkan pemerintah desa mengalokasikan anggaran dari kas desa sebesar Rp 8.000.000-Rp 12.000.000 untuk menyelenggarakan kabumi. Masyarakat juga turut berperan aktif dengan cara menyumbangkan makanan, uang, atau tenaga semampunya meskipun bukan petani. Mereka menganggap bahwa mereka juga turut menikmati hasil bumi dari pertanian dan sumur yang menjadi sentral ritual kabumi. Oleh karena itu perlu menunaikan sedekah atas panen dan sumber daya alam yang telah dinikmati.

Tradisi kabumi sebagai kearifan lokal dalam pertanian kini mengalami perubahan yang dipengaruhi oleh modernisasi dan infiltrasi agama dalam masyarakat. Modernisasi yang ditandai dengan determinannya rasionalitas dan kemajuan Iptek mengubah pandangan dunia (world view) masyarakat terhadap realitas kehidupan. Pemikiran masyarakat yang rasional cenderung menepikan hal-hal yang berbau mitos dan transendental sehingga secara langsung berimplikasi terhadap tradisi kabumi yang kental nuansa mistis. Seiring dengan infiltrasi ajaran Islam dalam kehidupan masyarakat Jatirogo, praktikpraktik mistik dalam kabumi mulai berubah. Hal tersebut dikarenakan sebagian masyarakat mulai menganggap praktik mistis tersebut tidak sesuai dengan ajaran Islam karena dianggap sirik.

Berdasarkan wawacara dengan LAN $(5 / 2020)$ terdapat beberapa perubahan sebagai konsekuensi bergesernya pandangan masyarakat. Berikut petikannya. 
"Dulu, Bawa makanan sebelum tayuban dimulai secara giliran di tiga sumur. Sekarang cukup milih di sumur yang paling dekat rumah tidak harus semuanya. Pemimpin doa kabumi adalah modin tapi dengan perintah kepala desa. Sekarang di bagi-bagi, pak kaur bagian mulai, modin bagian doa. Kalo sekarang siapa saja bisa. Dulu, kalo tidak moden belum sah".

Pandangan tersebut berimplikasi pada adanya perubahan dan menurunnya partisipasi masyarakat dalam prosesi kabumi. Ajaran-ajaran Islam dimasukkan dalam prosesi kabumi. Kabumi sebagai bentuk slametan tidak hanya dimaknai sebagai bentuk komunikasi dengan arwaharwah nenek moyang dan merawat solidaritas sosial sebagaimana menurut Geertz (Koentjaraningrat, 1984:346-347), melainkan juga rasa syukur kepada Tuhan atas rezeki yang dilimpahkan melalui hasil panen.

Adanya infiltrasi Islam dalam mistisisme dan tradisi lokal membentuk hibridasi antarketiganya yang lebih mengarah pada pandangan transendental keagamaan masyarakat (Beatty, 2001). Pandangan tersebut pada akhirnya lebih mendominasi pemaknaan masyarakat terhadap praktik kehidupan, termasuk juga dalam pertanian. Arah perkembangan tradisi pun lebih kental nuansa Islami.

Meskipun prosesi ritual kabumi dilangsungkan dengan cara Islami namun pelaksanaannya tetap harus di punden, bukan di musala maupun di masjid. Selain karena sudah menjadi tradisi, masyarakat menganggap bahwa kabumi di punden juga sebagai media interaksi masyarakat dengan arwah leluhur yang babad tanah Bader. Masyarakat masih mengagungkan tradisi sebagai peninggalan leluhur yang harus dilestarikan. Hal tersebut juga untuk menyeimbangkan hubungan antara dunia nyata dan supernatural.

Setelah penyerahan sesajen di tiga puden, ritual kabumi dilanjutkan dengan pertunjukkan hiburan sinder sampai siang bahkan larut malam, yakni tradisi tari oleh perempuan yang memang berprofesi sebagai penari. Sinder berbeda dengan tayub. Tayub melibatkan banyak orang sedangkan sinder dilakukan seorang diri. Pemilihan sinder sebagai hiburan karena dianggap kesukaan para danyang pada masa lalu. Masyarakat pernah menggantinya dengan pertunjukan wayang namun terjadi hal mistis, seperti gong dan peralatan sound system tidak berfungsi. Berdasarkan peristiwa mistis tersebut sinder tetap dipertahankan hingga kini.

Kemajuan zaman yang mewujud dalam modernisasi turut andil dalam perubahan tradisi kabumi. Modernisasi yang ditandai dengan kemajuan ilmu pengetahuan dan teknologi mulai menggeser pemahaman dan praktik-praktik mistis di masyarakat. Cara berpikir masyarakat cenderung rasional dengan mengutamakan perhitungan sarana tujuan (means-end calculation). Menurut Weber (Schroeder, 2002), hal tersebut telah memudarkan pesona aspek magis dan agama (disenchantment of the world) dalam memaknai realitas kehidupan.

Kemajuan Iptek melahirkan modernisasi dalam pertanian dengan beragam program dan bentuknya. Programprogram pemerintah dalam bidang pertanian yang kalkulatif dan prediktabel turut menggerus tradisi karena adanya perubahan pola pertanian. Program intensifikasi, ekstensifikasi, dan diversifikasi dari pemerintah untuk menggalakkan pertanian secara perlahan tapi pasti mengubah sistem subsisten dan gotong royong dalam mengelolah lahan (Soedjatmoko, 1995:7476). Masuknya teknologi dan produk-produk kimia juga mengubah pola tanam (pranata mangsa) masyarakat sehingga pelaksanaan kabumi berubah. Belum lagi adanya teknologi pertanian yang mengubah sistem pertanian dari yang subsisten dan gotong royong ke individual yang cenderung kalkulatif dan prediktabel (means-goal oriented). Tradisi kabumi yang dipercaya secara turun-temurun dapat menjaga keberlangsungan pertanian pun perlahan 
tergerus oleh implikasi-implikasi dari modernisasi.

Akibat dari perubahan pola tanam tersebut, pelaksanaan kabumi turut bergeser dan mengalami perubahan, namun tetap dilangsungkan pada hari rabu pon. Perubahan tidak hanya dalam pelaksanaan, namun juga relasi dengan desa tetangga. Hal tersebut karena ada kepercayaan turuntemurun bahwa pelaksanaan kabumi harus bersamaan dengan desa tetangga. Jika dilanggar, konsekuensinya adalah ada perbedaan kualitas hasil pertanian dan kondisi kesejahteraan masyarakat. Kepercayaan ini tetap dipegang teguh masyarakat meski banyak yang menganggapnya hanya mitos dan irasional. Kepercayaan tersebut muncul atas dasar pemahaman dan pengetahuan masyarakat generasi tua yang berdasarkan ilmu titen.

Beberapa masyarakat Jatirogo yang dahulu memandang ritual kabumi sebagai prosesi yang sakral dan perlu dilestarikan, kini beralih memandangnya sebagai praktik irasional yang mistis. Pandangan ini menyebabkan menurunnya partisipasi masyarakat dalam kabumi. Sebelumnya, masyarakat aktif berpartisipasi dalam kabumi meskipun tidak memiliki lahan pertanian. Hal tersebut karena mereka menganggap turut menikmati hasil bumi berupa sumber air yang dikeramatkan.

\subsection{Kabumi dan Internalisasi Nilai-Nilai Karakter Masyarakat Jatirogo}

Budaya diwariskan secara turuntemurun dari satu generasi ke generasi lainnya. Namun, dengan adanya gempuran globalisasi proses pewarisan tersebut bisa mengalami dinamika. Budaya kearifan lokal pada tiap daerah mempunyai sifat kedinamisan berbeda-beda dalam mengatasi berbagai tantangan dan pengaruh globalilasi. Dampak yang ditimbulkan tidak selalu negatif, namun ada juga dampak positifnya. Oleh karananya, dianggap perlu untuk mengembangkan knowledge management terhadap berbagai jenis kearifan lokal tersebut agar dapat digunakan sebagai acuan dalam proses perencanaan dan perencanaan pembangunan berkelanjutan.

Konsep pendekatan budaya menurut $\mathrm{Al}$ Muchtar (2004) dianggap mampu menjadi alternatif solusi dalam mengimbangi kelemahan pendekatan formalistik birokrasi yang selama ini digunakan. Pendidikan merupakan salah satu aspek transformasi kebudayaan yang mengharuskan partisipasi dari semua pihak. Dalam Undang-undang No 20 Tahun 2003 Tentang Sistem Pendidikan Nasional juga dijelaskan bahwa pendidikan tidak hanya dilakukan pada jenjang persekolahan/formal (SD, SMP, SMA, dan Perguruan Tinggi) saja melainkan juga melalui jenjang pendidikan informal dan non formal.

Tradisi-tradisi dalam pertanian mencerminkan kearifan lokal masyarakat dalam berinteraksi dan memanfaatkan lingkungan. Kearifan lokal mencakup pengetahuan, keyakinan, dan nilai-nilai budaya masyarakat yang mengatur hubungan sesama manusia, manusia dengan alam, dan manusia dengan Tuhan (Bustami, 2013: 9-10). Konteks kearifan lokal inilah yang menyebabkan masyarakat terkontrol dalam memanfaatkan sumber daya alam yang tersedia. Tindakan masyarakat harus didasarkan pada nilai-nilai yang disosialisasikan dan dipraktikkan secara turun-temurun.

Perubahan sosial membawa budaya ke arah kehidupan modern, selain itu warisan budaya dan nilai-nilai tradisional yang ada dalam masyarakat adat menghadapi tantangan dalam mempertahankan eksistensinya. Semua itu tentu menjadi fokus dan perhatian kita bersama, bahwa di satu sisi dampak negatif yang ditimbulkan oleh globalisasi adalah mampu menghilangkan warisan budaya dan nilainilai tradisional yang mengandung banyak kearifan lokal. Nilai-nilai yang ada dalam kearifan lokal tiap-tiap daerah yang dipandang relevan dengan kondisi saat ini 
seharusnya dilestarikan, diadaptasi, atau bahkan dikembangkan lebih jauh agar tidak hilang.

Nilai-nilai yang terkandung dalam kearifan lokal salah satunya adalah nilai karakter. Nilai-nilai karakter terdiri dari sembilan pilar nilai-nilai secara universal antara lain (1) cinta Tuhan dan segenap ciptaan-Nya, (2) kemandirian dan tanggung jawab, (3) kejujuran dan amanah, (4) hormat dan santun, (5) dermawan, suka menolong, kerja sama, (6) percaya diri dan pekerja keras, (7) kepemimpinan dan keadilan; (h) baik dan rendah hati, dan (8) toleransi, kedamaian, dan kesatuan (Azzet, 2011). Nilai-nilai tersebut diinternalisasikan pada masyarakat melalui berbagai media dan pendekatan.

Internalisasi nilai, menurut Widyaningsih et. al. (2014), memerlukan beberapa tahapan antara lain (1) Tahap penerimaan nilai. Pada tahap ini nilai diterima oleh seseorang dengan berbagai cara, antara lain dengan mendengarkan, melihat, dan membaca buku. Melalui indra pendengar dan penglihat masyarakat memperoleh pengetahuan tentang nilai, kebaikan, keburukan, dan manfaatnya bagi kehidupan. (2) Tahap memberikan respon atau menanggapi. Proses merespon dilakukan setelah seseorang mendapatkan pengetahuan nilai. (3) Tahap seleksi nilai. Dalam proses ini berlangsung setelah seseorang telah menerima beberapa nilai dalam dirinya. Beberapa nilai yang telah seseorang terima akan diseleksi dalam diri sendiri. (4) Tahap internalisasi atau penghayatan nilai. Proses menghayati nilai mengandung makna mengalami dan merasakan nilai-nilai tersebut dalam batinnya. Menghayati atau mempribadikan nilai juga mengandung arti merasakan betulbetul tentang nilai-nilai yang telah diterima sampai dalam relung hati sehingga menumbuhkan kesadaran dalam dirinya untuk melakukan nilai tersebut. (5) Tahap aktualisasi atau penerapan nilai. Tahapan ini merupakan tahap terakhir proses internalisasi nilai. Penerapan ini akan terjadi setelah melalui proses penghayatan nilai. Seseorang yang telah menghayati nilai maka akan mendorong dirinya untuk mengaktualisasikan nilai tersebut dalam perilakunya. Orang tersebut telah memiliki kesadaran pada dirinya sendiri untuk menerapkan nilai-nilai tersebut dalam kehidupannya.

Terkait dengan proses internalisasi nilai yang ada dalam kearifan lokal kabumi di awali dari tahap penerimaan nilai. Masyarakat Desa Bader mengenal kabumi dari nenek moyang mereka secara langsung. Tradisi ini terus dilakukan setiap tahun, berdasarkan perhitungan tertentu. Terdapat berbagai nilai yang muncul dalam kabumi, antara lain nilai religius, nilai gotong royong, toleransi, dan peduli lingkungan. Tahap kedua yaitu memberikan respon atau menanggapi. Dalam tahapan ini masyarakat memberikan respon positif nilai-nilai yang ada dalam kabumi. Nilai-nilai yang muncul tersebut kemudian diajarkan dan diwariskan secara turun temurun. Tahapan ketiga yaitu seleksi nilai. Dalam tahapan ini masyarakat melakukan seleksi nilai pada dirinya sendiri setelah mereka menerima nilai dan melakukan respon terhadap nilai-nilai yang ada/terkandung dalam kabumi. Secara umum pada tahapan ini nilai-nilai yang terkandung dalam kabumi tidak mengalami reduksi. Tahapan keempat adalah penghayatan nilai. Pada tahapan ini nilainilai yang ada tersebut melekat pada diri masyarakat dan menjadi sebuah karakter. Tahapan yang terakhir yaitu aktualisasi. Nilai-nilai yang terkandung dalam kabumi tersebut diimplementasikan dalam kehidupan sehari-hari.

Berdasarkan tahapan internalisasi nilainilai karakter tersebut maka beberapa nilai yang muncul dari kearifan lokal kabumi sebagai berikut. Pertama, nilai religius. 
Masyarakat Indonesia merupakan masyarakat yang menjunjung tinggi nilainilai agama. Hal ini secara jelas juga tertuang dalam Undang-undang Dasar Negera Republik Indonesia Tahun 1945 Pasal 29 Ayat (1) yaitu "negara berdasar atas Ketuhanan Yang Maha Esa". Pandangan lain yang menyatakan bahwa masyarakat Indonesia adalah masyarakat yang religius diungkapkan oleh Thomas Brandt (Panggabean et. al., 2014) sebagai berikut:

"Indonesia's will be qiute a new challenge to any Westerners in terms of religion. He will rediscover tolerance, the relationship between religion and society, and the significance of religion in everyday life"

Nilai religius sebagai nilai budaya ditunjukkan dalam sejumlah folklor Indonesia, seperti cerita, hikayat, dongeng, dan legenda. Manifestasi penyatuan agama dan budaya yang ada di Jawa, misalnya timbulnya agama Kejawen.

Nilai religius dalam kearifan lokal kabumi terlihat dari adanya kegiatan keagamaan yang dilakukan dalam ritual. Ritual doa diadakan di punden sesuai dengan agama dan kepercayaan masing-masing. Nilai religius ini tidak hanya bias pada satu agama saja, tetapi justru menguatkan toleransi beragama dalam masyarakat lintas agama.

Kedua, nilai gotong royong. Menurut Efendi (2013) gotong royong merupakan budaya yang tumbuh dan berkembang yang diwariskan secara turun temurun pada kehidupan sosial masyarakat Indonesia. Sebagai suatu bentuk kerja sama yang dilakukan oleh masyarakat, gotong royong dilakukan untuk mencapai hasil yang positif berdasarkan musyawarah mufakat. Masyarakat Desa Bader secara bersamasama melakukan kegiatan gotong royong saat musyawarah dalam penetapan kabumi, kemudian terlihat dari adanya kebersamaan bersama masyarakat dalam melakukan ritual kabumi. Musyawarah melibatkan banyak elemen masyarakat sehingga dapat mewadahi pendapat dan kepentingan masyarakat secara keseluruhan. Proses ini penting untuk menguatkan demokrasi di tingkat lokal melalui musyawarah untuk mencapai mufakat.

Ketiga, nilai toleransi. Toleransi merupakan pengakuan terhadap the right of self determination atau hak untuk menentukan sendiri nasib masing-masing individu (Zuhroh \& Solihuddin, 2019). Artinya, seseorang mempunyai tanggung jawab sendiri-sendiri terhadap hidupnya. Namun yang perlu dipahami dalam melakukan pertahanan hidup seseorang tidak boleh melanggar hak orang lain. Wujud toleransi bisa berupa sikap dan kerja sama. Nilai toleransi yang terlihat dari adanya sikap saling menghormati baik antar masyarakat yang berbeda keyakinan maupun masyarakat yang tidak mengikuti ritual kabumi. Masyarakat Desa Bader merupakan masyarakat yang toleran karena mampu menerima perbedaan yang ada di dalam masyarakat baik yang berkaitan dengan agama, suku, ataupun ras.

Keempat, nilai peduli lingkungan. Menurut Purwati (2017) peduli lingkungan merupakan suatu sikap dan tindakan yang berupaya mencegah kerusakan yang terjadi pada lingkungan alam di sekitarnya dan mengembangkan upaya-upaya untuk melakukan perbaikan pada kerusakan alam. Jadi peduli lingkungan diwujudkan dengan tindakan preventif dan juga perbaikan bagi keadaan alam yang rusak. Nilai peduli lingkungan terlihat dari adanya sikap menjaga dan melestarikan lingkungan desa.

\section{Kesimpulan}

Kearifan lokal berperan penting dalam kehidupan masyarakat di tengah gencarnya arus modernisasi dan dampaknya terhadap perubahan sosial. Kabumi sebagai salah satu 
kearifan lokal dalam konteks ini menjadi media penting internalisasi nilai-nilai karakter di masyarakat. Hasil penelitian menunjukkan bahwa proses internalisasi nilai-nilai karakter dilakukan melalui lima tahapan, yaitu penerimaan nilai, memberikan respon, seleksi nilai, internalisasi, dan aktualisasi. Nilai-nilai karakter yang muncul sebagai bentuk internalisasi nilai-nilai karakter melalui kearifan lokal kabumi antara lain nilai religius, gotong royong, toleransi, dan peduli lingkungan. Penelitian ini menguatkan argumen bahwa kearifan lokal berperan penting dalam internalisasi nilai-nilai. Kabumi dalam hal ini menjadi salah satu sebagai media internalisasi pendidikan karakter bagi masyarakat di Desa Bader, Kecamatan Jatirogo, Kabupaten Tuban. Oleh karena itu, sebagai rekomendasi, revitalisasi kearifan lokal penting dilakukan untuk internalisasi nilai-nilai karakter di masyarakat.

\section{Daftar Pustaka}

Al Muchtar, S. (2004). Pendidikan dan Masalah Sosial Budaya. Bandung: Gelar Pustaka Mandiri.

Azzet, A. M. (2011). Urgensi Pendidikan Karakter Di Indonesia: Revitalisasi Pendidikan Karakter Terhadap Keberhasilan Belajar dDan Kemajuan Bangsa. Jakarta: Ar Ruzz Media.

Beatty, A. (2001). Variasi Agama di Jawa, Suatu Pendekatan Antropologi. Jakarta: Raja Grafindo Persada.

Bustami, A. L. (2013). Sasi: Kearifan Lokal masyarakat Maluku Tengah mengelola Lingkungan. Kementerian Pendidikan dan Kebudayaan Direktorat Jenderal Kebudayaan Direktorat Internalisasi Nilai dan Diplomasi Budaya

Effendi, N. T. (2013). Budaya Gotong Royong Masyarakat dDalam Perubahan Sosial Saat Ini. Jurnal Pemikiran Sosiologi, 2 (1), 1-18. Doi: https://doi.org/10.22146/jps.v2i1.2340
Gobyah. (2003). Pengenalan Keraifan Lokal Indonesia. Rineka Cipta: Jakarta

Lemianti, Y., Nuwa, G., \& Kpalet, G. N. (2020). Nilai-nilai Kearifan Lokal Gong Waning Pada Masyarakat Etnis Sikka Krowe Sebagai Sumber Pendidikan Karakter. Edu Teach: Jurnal Edukasi dan Teknologi Pembelajaran, 1 (2), 1848-53. Retrieved from http://www.ejurnal.umri.ac.id/index.ph $\mathrm{p} /$ eduteach/article/view/1953

Hadi, N. (2013). Perilaku Adat Efektif Petani Sayur Tengger pada Lahan Miring di Kantong Taman Nasional Bromo Tengger Semeru (BTS). Jurnal Studi Sosial. Lembaga Penelitian dan Pengabdian Malang (LP2M) Universitas Negeri Malang.

Hardika. (2009). Transformasi Sosial Masyarakat Transisi: Eksistensi Kearifan Lokal dan pergeseran perilaku Usaha Petani. Jurnal Studi Sosial. Lembaga Penelitian dan Pengabdian Malang (LP2M) Universitas Negeri Malang.

Hartati, S. T. D. (2012). Peranan Dewi Sri dalam Tradisi Pertanian di Indonesia. Ikatan Ahli Arkeologi Indonesia. Blog. https://iaaipusat.wordpress.com/2012/0 4/08/peranan-dewi-sri-dalam-tradisipertanian-di-indonesia/ Diakses pada 11 Juli 2017 jam 11.

Iskandar, J. (2016). Etnobiologi dan Keragaman Budaya Indonesia. Umbara, 1(1) 27-42. doi: https://doi.org/10.24198/umbara.v1i1.9 602

Jamiah, Y. (2011). Internalisasi Nilai Sosial dan Budaya Bagi Pendidikan Anak Usia Dini (PAUD) Melalui Pembelajaran Matematika Kreatif. Guru Membangun, 26 (2), 1-11. Retrieved from https://jurnal.untan.ac.id/index.php/jgm $\mathrm{m} /$ article/view/309/315

Koentjaraningrat. (1984). Kebudayaan Jawa. Jakarta: Balai Pustaka 
Lestari, G. (2015). Bhinneka Tunggal Ika: Khazanah Multikultural Indonesia Di Tengah Kehidupan Sara. Jurnal Pendidikan Pancasila dan Kewarganegaraan, 28 (1), 31-37

Mahardika, I. W. T., \& Darmawan, C. (2016). Civic Culture Dalam Nilai-nilai Budaya dan Kearifan Lokal Masyarakat Bali Aga Desa Truyan. Humanika, 23 (1), 20-31. Retrieved from https://ejournal.undip.ac.id/index.php/h umanika/article/view/11761

Maisyanah, M., \& Inayati, L. (2019). Internalisasi Nilai Pendidikan Agama Islam Pada Tradisi Meron. Edukasia: Jurnal Penelitian Pendidikan Islam, 13(2), 329-350. Retrieved from http://journal.iainkudus.ac.id/index.php /Edukasia/article/view/4627

Panggabean, H., Tjitra, H., \& Murniati, J. (2014). Kearifan lokal keunggulan global: Cakrawala baru di era globalisasi. Jakarta: PT Elex Media Komputindo

Purwanti, D. (2017). Pendidikan Karakter Peduli Lingkungan dan Implementasinya. Dwija Cendekia: Jurnal Riset Pedagogik, 1 (2), 14-20. Retrieved from https://jurnal.uns.ac.id/jdc/article/view/ 17622

Ridwan, N. A. (2007). Landasan Keilmuan Kearifan Lokal. Jurnal Studi Islam dan Budaya, 5 (1), 27-38.

Ritzer, G. (2010). Enchanting a disenchanted world: Continuity and change in the cathedrals of consumption. Pine Forge Press

Schroeder, R. (2002). Max Weber, Tentang Hegemoni Sistem Kepercayaan. Terj. Ratna Noviani. Yogyakarta: Kanisius.

Soedjatmoko. (1995). Dimensi Manusia dalam Pembangunan. Jakarta: LP3ES.

Sudarma, I. K. (2007). 'Laporan penelitian: studi ananlisis kebutuhan pendidikan multikultural berbasis kompetensi pada siswa sekolah dasar di kota singaraja'. Singaraja: Undiksha

Tabloid Desa. (2016). Ritual Adat di setiap Aktivitas Pertanian (Tabloid Desa Edisi 20- periode 21 November-6 Desember 2016

Widyaningsih, T. S., Zamroni., \& Zuchdi, S. (2014). Internasilasi dan Aktualisasi Nilai-nilai Karakter Pada Siswa SMP dalam Perspektif Fenomenologis. Jurnal Pembangunan Pendidikan: Fondasi dan Aplikasi, 2 (2), 181-195.

Zuhroh, K., \& Baharuddin, M. A. (2019). Nilai-nilai Toleransi Antar Sesama dan Antar Umat Beragama: Studi Pandangan K.H Sholeh Baharuddin. Journal Multicultural of Islamic Education, 3 (1), 41-55. 